\title{
AID FOR FOOD SECURITY: DOES IT WORK?
}

Ivica Petrikova, University College London

(forthcoming in the International Journal of Development Issues)

\section{Structured Abstract:}

\section{Purpose}

The paper's objective is to contribute to existing literature by examining whether development aid has any measurable impact on food security, whether the impact is conditioned on the quality of governance, and whether it differs based on the type of aid provided.

\section{Methodology}

Panel-data analysis of 85 developing countries between 1994 and 2011, employing GMM and 2SLS estimators.

\section{Findings}

The paper finds that aid in general has a small positive impact on food security; that multilateral aid, grants, and social and economic aid have a positive effect on food security in their own right; and that bilateral aid, loans, and agricultural aid are more conditioned on the quality of governance that other aid.

\section{Research Limitations}

The main limitations rest with the imperfect nature of cross-country data on food security and governance, which I have tried to overcome through a series of robustness tests.

\section{Practical Implications}

The findings suggest that aid, despite its many deficiencies, can play a positive role in strengthening food security. Furthermore, they indicate that concessional loans, bilateral aid, and agricultural aid are likely to foster food security only in countries with better governance.

\section{Originality/Value}

The paper constitutes a novel contribution to existing literature because it is one of the first to use cross-country data to explore the impact of aid on food security and because it utilizes a relatively complex aid categorization, which allows its conclusions to be more nuanced.

\section{Keywords:}

Food security, development aid, governance, heterogeneous impact 


\section{Introduction}

Food security worldwide experienced significant improvements in the latter half of the twentieth century. However, events from recent years, including the 2008 global food price crisis and the 2012 famines in the Sahel and the Horn of Africa suggest that this positive trend has been reversed (Webb, 2010). Growing world population, diversifying consumption patterns in China and India, and deteriorating climate conditions are exerting an ever increasing pressure on the world's food resources and thereby worsening global food availability and food access (Leisinger et al., 2002).

Policy practitioners and researchers widely agree that countries adversely affected by food insecurity should invest greater funds into efforts addressing the problem. Nevertheless, many developing countries lack the ability to mobilize sufficient resources domestically. One potential way to fill these financial gaps is through development aid and advanced economies have been quite vocal about their desire to strengthen food security through financial assistance. For example, at the 2009 summit in l'Aquila, Italy, the G8 countries promised to donate 22 billion USD to global food-security efforts over the following three years (G8, 2009). At the end only half the funds were delivered but the 2012 G8 summit conclusions reiterated the countries' commitment to continue tackling global food insecurity through development aid (G8, 2012).

Existing research has investigated the link between aid and economic growth quite extensively but the relationship between development assistance and food security remains largely unexplored. Here, I hope to fill this void and then proceed beyond it. Aid from different donors, in different forms, and to different sectors may have varying impacts on its recipients' food security. Moreover, the quality of the beneficiaries' institutions and policies might have a bearing on the relationship as well. In this paper I examine whether aid, generally and in its various forms, has any measurable effect on food security and whether this effect is influenced by the recipients' quality of governance. I carry out the analysis on a cross-country level of all developing countries, rather than on a regional or national level, in order to ensure greater data availability and reveal a global pattern of aid-food security relationships.

\section{Food security, development aid, and governance}

\section{Defining the key concepts}

Both the Food and Agriculture Organization (FAO) and the World Health Organization (WHO) define food security as a state in which 'all people at all times have access to sufficient, safe and nutritious food to maintain an active and healthy life.' Food security thus rests on four pillars - food availability, access to food, food utilization ${ }^{[1]}$, and stability of the previous three pillars (Barrett, 2002). Food security and its reverse, food insecurity, embody ex ante conditions, with states such as hunger, malnutrition and undernourishment the corresponding ex post concepts. Due to a lack of suitable data, it is only the ex post conditions which can be measured comparatively on the global scale. Available candidates in this regard include food insecurity measures calculated periodically by the FAO, such as the prevalence of undernourishment, and children's nutritional indicators provided by the WHO. These variables do not capture the full complexity of food insecurity but, as Svedberg (2000) implies, if used in combination they can act as valid approximates.

Development aid refers to the financial flows from richer to poorer countries, with the main official goal of promoting economic, social, political and environmental development (Organization for Economic Co-operation and Development [OECD], 2003). No unified classification of aid exists; however, for the purposes of this paper I suggest a simple division according to three dimensions: who provides aid, how it is disbursed, and where it goes. 
In the first category, based on the donor's identity, the obvious categorization is into aid provided by multilateral and by bilateral agencies. In the second category, which examines how aid is distributed, I include two divisions, one into grants and concessional loans and one into budget support versus program and project aid. In the last dimension of aid categorization, according to where aid flows, I use a division of aid based on the sector where it was invested - in agriculture, in social infrastructure, in economic infrastructure or in the remaining sectors $^{[3]}$. This specific categorization has not been used by researchers thus far but seems very relevant when investigating the effect of aid on food security, as mostly agricultural aid tends to be linked with food security, at least on the household level (e.g. Berti et al, 2003; IYCN, 2011).

Governance as a theoretical concept is still only in its embryonic stage, as Abdellatif (2003:3) points out, and hence its precise definition often varies in line with authors' differing ideological convictions. Some believe that it represents the process by which authority in a country is exercised, others understand it as the mechanisms and institutions that enable such process, while yet others include in the definition also the outcomes of the process, i.e. policies (ibid). The donor world became interested in measuring the quality of governance in the developing world after papers by Kormendi and Meguire (1985) and Scully (1988) suggested that aid had a more positive effect on growth in countries with better institutions and policies. The World Bank and the OECD eventually followed with their own definition of 'good' governance, to which I adhere in this paper, as institutions and policies that are "participatory, consensus oriented, accountable, transparent, responsive, effective and efficient, equitable and inclusive, and follow the rule of law' (OECD, 2003).

\section{The aid-food security-governance link, in theory and in reality}

On the macro level, researchers have to date studied predominantly the impact of aid on countries' economic growth. However, raising growth rates is only one of several objectives that development aid purportedly aims to achieve. As mentioned above, the main official goal of development assistance is to encourage economic, social, political, and environmental development and thus contribute to comprehensive poverty alleviation. Since food security constitutes a key element of poverty alleviation ${ }^{[4]}$, all development aid should on paper be making its recipients more food secure. Examining whether that has indeed been the case is hence important.

Since food security constitutes a multifaceted phenomenon, its theoretical link with aid is also complex. Through its impact on growth, aid might affect the food supply aspect of food security. By helping to raise per-capita income levels, aid can strengthen the access-to-food aspect. The connection between aid and the third pillar of food security is less straightforward, but by improving nutritional education and health and sanitation infrastructure, aid could contribute to improving people's food utilization. Finally, aid is also likely to have an impact on the last aspect of food security, stability, but even in theory it is hard to identify its direction as it depends on the country's specific situation, including its relationship with donors. Despite this ambiguity, in theory aid flows should be helping countries reduce domestic food insecurity.

Whether this hypothesis holds in reality remains largely a matter of empirical investigation, however. As I mentioned, very few researchers thus far investigated the relationship between aid and food security specifically even though works on aid effectiveness in other areas of development abound. An overwhelming majority of literature on the effect of aid on growth found a significant and positive impact (e.g. Bhavan et al., 2011; Lensink and White, 2001; Burnside and Dollar, 2000) even though some studies suggested that the results were fragile to changing specifications and samples (Doucouliagos and Paldam, 2009). The research on the effects of aid on income levels and poverty reduction is less conclusive but still leans towards positive findings (Kosack, 2003; Masud and Yontcheva, 2005). The effects of aid on sectors 
that could improve food utilization, such as education, health, and water and sanitation, have been less studied but some works did discover a positive relationship (e.g. Mishra and Newhouse, 2007; Dreher et al., 2008). On the other hand, research indicates that at least in some situations aid negatively affects the stability aspect of food security, by exacerbating recessions with its pro-cyclical downturns (Bulir and Hamann, 2008).

The cautious optimism with which researchers generally view aid effectiveness is not quite replicated with regard to the intervening role of 'good' governance. In theory it appears probable that aid works better in countries with more accountable and less corrupt institutions and policies. However, although many researchers indeed concluded that the impact of aid was more pronounced in countries with better governance (e.g. Burnside and Dollar, 2000; Clemens et al., 2004), others found the quality of governance to be of no significance (Dalgaard and Hansen, 2001; Morrissey, 2004).

\section{The role of aid heterogeneity}

Aid constitutes a highly varied flow of funds and hence it appears likely that some types might be more beneficial to development objectives, food security included, than others. It has not become common practice thus far to open the 'black box' of aid when examining aid effectiveness empirically but some studies on the heterogeneous effects of different aid modalities do exist. Vis-à-vis who gives aid, multilateral aid should theoretically be more supportive of official development objectives than bilateral aid since political and commercial interests are less likely to play a role in its disbursements. For the same reasons, 'good' governance is probably more important in ensuring the effectiveness of bilateral aid. Existing research has shown the first claim to generally hold true (Balogh, 1967; Burnside and Dollar, 2000) but has to date not examined validity of the second one.

The consequences of the decision how to deliver aid are more theoretically ambiguous. Regarding the division of aid into grants and concessional loans, grants could be seen as the more beneficial mechanisms since they do not indebt the recipients' governments. On the other hand, they could cultivate a culture of dependency, thereby weakening the recipients' own institutions and their resilience. Empirical findings have supported both points of view (Bullow and Rogoff, 2005; Djankov et al., 2006). Nonetheless, whichever the truth, governance should play a more pronounced role in ensuring the positive effect of loans since their administration - particularly the fact that they have to be repaid - requires greater fiscal discipline from the recipients. However, this argument has not been empirically proven so far.

Regarding the choice between program/project aid and budget support, budget support can be seen as a more useful financing mechanism as it is provided directly to governments and hence does not create an alternative administrative structure as projects and programs might do (Devarajan and Swaroop, 1998, Crola, 2009). On the other hand, similar to the case of loans, budget support is likely to be more susceptible to the influence of governance because it relies to a larger extent on domestic actors, institutions, and policies than program and project aid. Previous research indeed suggested that governance might play a significant conditioning role in aid effectiveness (Cordella and Dell'Arricia, 2003) and consequently some donors, notably the European Commission, use the strictest form of conditionality in their disbursements of budget support.

As mentioned already, the classification of aid according to where it flows is into agricultural, social, economic, and other aid. Theoretically, one could expect aid to agriculture to have a more positive impact on food security than aid to any other sector as it specifically aims at improving food production. Some researchers proved the existence of a positive link between agricultural aid and food security empirically but predominantly on the micro level (e.g. IYCN, 2011). Social and economic aid should in theory also bolster food security, through better health, education, and economic opportunities but it is easy to imagine situations in 
which such desired outcome is not achieved because the aid provided fails to reach the truly impoverished layers of society.

\section{Summary of hypotheses}

In light of the theoretical postulations and existing research, I expect to find that aid in general has a positive although not a very robust impact on food security. I am less confident with regard to the conditioning effect of governance. Logically I would anticipate the impact of aid to appear more positive in countries with a higher quality of institutions and policies but empirical research has not always confirmed this provision to hold true.

When investigating the heterogeneous impact of aid on food security, I expect to find multilateral aid to be more beneficial than bilateral aid, grants to be more beneficial than loans, and agricultural aid to bolster food security more than other types of aid. Regarding the conditioning role of 'good' governance in different aid types, I conjecture that it is significant primarily in ensuring the positive impact of bilateral aid, concessional loans, and budget support.

\section{Data}

\section{Food (in)security}

As food insecurity measures, I use the FAO's prevalence of undernourishment and the WHO's proportion of children younger than five years that are underweight (too light for age). The two variables measure similar but not identical concepts. Most notably, the underweight indicator is a more conservative measure of food insecurity as parents generally do their utmost to feed their children adequately even if they lack the resources to do so for themselves (Dinour et al., 2007). Consequently, mild food insecurity might result in raising undernourishment prevalence in adults without affecting the prevalence of underweight children.

\section{Development aid}

Data on official development assistance (ODA) flows are available from the Credit Reporting System (CRS) of the OECD. Data on aid flows in general and on the divisions into bilateral and multilateral aid as well as into grants and loans are available in constant 2011 USD disbursements. Unfortunately, disbursement data divided according to the sectors where the aid was spent are available only after 2002 and incomplete. Therefore, in these instances I use data on the aid committed, available from 1995 onwards.

In examining the impact of aid on food security in general, I follow majority of researchers and use a measure of aid disbursed per recipient's GDP (natural logarithm, lagged by one time period). Nevertheless, since the categorization of aid is available only for gross aid flows, instead of using only net aid receipts as most researchers do, I use data on gross aid receipts and control for repayments (following Clemens et al., 2004).

When investigating the differential impact of multilateral versus bilateral aid, I substitute ODA per GDP with bilateral aid per GDP and multilateral aid per GDP. I follow the same logic with respect to the divisions into grants and concessional loans, and into agricultural, economic, social, and other aid. In these categorizations, I abide by the existing groupings within the CRS database. However, when exploring the impact of general budget support on recipients as opposed to the effect of program/project aid, I include a proportion of aid provided as budget support together with a measure of total ODA per GDP. I do so because the amount of aid provided as budget support is often miniscule relative to the rest of aid and if included in dollar terms its impact would be harder to detect. 


\section{Governance}

As a measure of governance, I considered two different variables. The first option was to follow Burnside and Dollar (2000) and use a weighted policy index composed of budget balance, trade openness, and inflation. However, while these aspects of governance appear relevant when examining the impact of aid on economic growth, they do not seem equally important when looking at aid's effect on food security. Consequently, I opted to use the World Bank's World Governance Indicators (WGI), measured on a scale from -2.5 to 2.5, with higher numbers denoting better governance. The WGI rates countries on six dimensions - voice and accountability, political stability and absence of violence, government effectiveness, regulatory quality, rule of law, and control of corruption - and thus complies more comprehensively with the World Bank's definition of 'good' governance cited earlier than the policy index. However, as a robustness check, in the sensitivity analysis I examine the impact of aid when conditioned on the weighted policy index as well.

\section{Control variables}

Following a wide range of researchers, as control variables I include a logarithm of GDP per capita, a logarithm of emergency food aid flows, debt repayments, a dummy variable for Least-Developed Countries (LDC), a logarithm of total population, a domestic food production index, a global food price index, a conflict dummy variable, a trade openness measure ${ }^{[5]}$, and a measure of social and economic rights (Cohen, 1995, Leisinger et al., 2002, Berg and Krueger, 2003, Kang and Meernik, 2005, del Ninno et al., 2007). All the control variables, just like the measures of aid and governance, are used in regressions lagged by one time period to ensure the correct temporal sequence. The conflict data came from the Uppsala Conflict Data Program, the rights data from the Cingranelli-Richards' dataset, and the rest of the variables from the World Development Indicators and from the FAO. Initially I also included a measure of political and civil rights and a dummy variable for disaster; however, as both appeared consistently insignificant I excluded them from the final analysis.

\section{Final dataset}

The final dataset is an unbalanced panel, comprising data in three-year averages from 1994 to 2011 for 85 developing countries. The year 2011 is the last year for which data were available as of the time of research; 1994 was chosen as the lower cut-off point due to the unavailability of data on several independent variables prior to that date. The data were averaged over threeyear periods to take into account the potentially cumulative effects of aid (following Burnside and Dollar, 2000).

\section{Summary statistics}

Table 1 displays descriptive statistics for all the variables used in my study. Looking first at the dependent variable, the numbers show that global food security improved between the first wave and the last wave of the data; however, the percentage reduction in undernourished population is more remarkable than in under-five children that are underweight. This finding is disappointing to some extent, as undernourishment in the first years of life carries more significant negative long-term consequences for human development than undernourishment later in life.

Regarding the main independent and conditioning variables, Table 1 shows that on average, the countries examined received less aid per GDP in 2009-11 than in 1994-1996 but that the decrease has been quite small. In all the aid categories assessed there was a decrease except for grants and social aid, which slightly increased. Interestingly, the two governance measures examined display a varying time trend. Whereas WGI scores on average slightly worsened 
between the first and the last wave of the data examined, the policy index improved significantly.

Turning attention to the summary statistics of the control variables utilized, most measures increased on average between the first and the last time period under study - including GDP per capita, food production index, trade openness, global food prices, and population. It is encouraging to see that fewer countries were involved in an active conflict in 2009-11 than in 1994-96 but less so that the mean score on social and economic rights deteriorated in that time frame. Average repayments and emergency food aid declined as well.

Table 1. Summary statistics of all key variables used

\begin{tabular}{|c|c|c|c|c|c|c|c|c|}
\hline \multirow{2}{*}{$\begin{array}{l}\text { Time period } \\
\text { Food (in)security }\end{array}$} & \multicolumn{4}{|c|}{ 1994-96 } & \multicolumn{4}{|c|}{ 2009-11 } \\
\hline & Mean & Std Dev & Min & $\operatorname{Max}$ & Mean & Std Dev & Min & $\operatorname{Max}$ \\
\hline Undernourishment prevalence (\%) & 22.34 & 15.48 & 0.00 & 60.83 & 17.02 & 13.56 & 0.00 & 68.37 \\
\hline Underweight children $(\%,<5$ yrs $)$ & 19.50 & 12.88 & 0.70 & 51.17 & 17.01 & 10.27 & 3.40 & 30.92 \\
\hline \multicolumn{9}{|l|}{ Development aid } \\
\hline Aid per GDP (xmillion) & 0.08 & 0.08 & 0.00 & 0.35 & 0.07 & 0.08 & 0.00 & 0.40 \\
\hline Bilateral aid per GDP & 0.05 & 0.06 & 0.00 & 0.31 & 0.04 & 0.04 & 0.00 & 0.24 \\
\hline Multilateral aid per GDP & 0.04 & 0.05 & 0.00 & 0.23 & 0.03 & 0.04 & 0.00 & 0.16 \\
\hline Concessional loans per GDP & 0.03 & 0.04 & 0.00 & 0.15 & 0.02 & 0.02 & 0.00 & 0.11 \\
\hline Grants per GDP & 0.06 & 0.08 & 0.00 & 0.35 & 0.07 & 0.08 & 0.00 & 0.40 \\
\hline Budget support per GDP & 0.01 & 0.02 & 0.00 & 0.08 & 0.01 & 0.01 & 0.00 & 0.05 \\
\hline Program/project aid per GDP & 0.07 & 0.08 & 0.00 & 0.35 & 0.06 & 0.08 & 0.00 & 0.40 \\
\hline Agricultural aid per GDP & 0.01 & 0.01 & 0.00 & 0.04 & 0.01 & 0.01 & 0.00 & 0.05 \\
\hline Social aid per GDP & 0.03 & 0.03 & 0.00 & 0.14 & 0.04 & 0.04 & 0.00 & 0.19 \\
\hline Economic aid per GDP & 0.02 & 0.02 & 0.00 & 0.07 & 0.02 & 0.02 & 0.00 & 0.10 \\
\hline Other aid per GDP & 0.01 & 0.01 & 0.00 & 0.02 & 0.01 & 0.02 & 0.00 & 0.13 \\
\hline \multicolumn{9}{|l|}{ Governance } \\
\hline WGI & -0.46 & 0.52 & -1.66 & 1.01 & -0.50 & 0.55 & -1.46 & 1.20 \\
\hline Policy & 47.21 & 112.67 & -578.20 & 158.97 & 83.24 & 43.09 & 17.47 & 203.27 \\
\hline Control variables & Mean & Std Dev & Min & $\operatorname{Max}$ & Mean & Std Dev & $\operatorname{Min}$ & $\operatorname{Max}$ \\
\hline GDP(PPP) p.c. & 1832 & 2245 & 131 & 12464 & 2231 & 2341 & 152 & 9029 \\
\hline Emergency food aid p.c. (x10) & 0.03 & 0.09 & 0.00 & 0.82 & 0.04 & 0.07 & 0.00 & 0.41 \\
\hline Population (in millions) & 58.2 & 185.0 & 0.8 & 1250.0 & 69.9 & 214.0 & 0.5 & 1340.0 \\
\hline Food production index & 82.5 & 11.4 & 48.3 & 141.6 & 125.3 & 17.3 & 85.7 & 166.1 \\
\hline Trade openness & 69.2 & 37.3 & 19.3 & 215.8 & 77.9 & 32.3 & 24.6 & 166.3 \\
\hline Social and economic rights & 7.73 & 3.55 & 0.33 & 13.67 & 6.87 & 3.45 & 0.00 & 13.00 \\
\hline Conflict & 0.31 & 0.46 & 0.00 & 1.00 & 0.28 & 0.45 & 0.00 & 1.00 \\
\hline World food price index & 1.79 & 0.37 & 1.04 & 2.63 & 1.91 & 0.37 & 1.23 & 2.86 \\
\hline LDC & 0.37 & 0.49 & 0.00 & 1.00 & 0.42 & 0.50 & 0.00 & 1.00 \\
\hline Repayments (in billions) & 1.31 & 3.14 & 0.00 & 20.30 & 1.28 & 2.83 & 0.00 & 15.90 \\
\hline$N$ of observations & \multicolumn{4}{|c|}{75} & \multicolumn{4}{|c|}{71} \\
\hline
\end{tabular}

Source: author's own calculations

\section{Empirical Analysis}

Data on aid and food security suffers from both autocorrelation and endogeneity. The Arellano-Bond (1991) test repeatedly shows that food security data is correlated to the first order; i.e. that the food security level in the current time period is correlated with the level in the previous time period. Regarding endogeneity, aid can hardly be expected to be completely 
exogenous to food security as countries with higher insecurity levels are more likely to receive larger amounts of aid.

The common manner of resolving these problems in the cross-country aid literature is to either use two-stage least-squares (2SLS) regressions or dynamic panel regressions (Clemens et al., 2004; Dreher et al., 2008). For my primary analysis, in which I examine the impact of aid in general on food security, I use both approaches. First, I analyze the data with a two-stage least-squares regression with country fixed effects, using the following model:

$$
\begin{aligned}
& \text { (1) } f_{i t}=\beta_{0}+\beta_{1} A^{\prime}{ }_{i t}+\beta_{2} G_{i t}+\beta_{3}\left(A^{\prime}{ }_{i t}{ }^{*} G_{i t}\right)+\beta_{4} X_{i t}+\gamma_{t}+\varepsilon^{f}{ }_{i t} \\
& \text { (2) } A^{\prime}{ }_{i t}=\delta_{0}+\delta_{1} I V_{i t}+\delta_{2} X_{i t}+\gamma_{t}+\varepsilon^{a}{ }_{i t}
\end{aligned}
$$

where $\beta_{0}$ and $\delta_{0}$ are constants, $f_{i t}$ is the prevalence of undernourishment observed for country $i$ in year $t, A_{i t}$ are aid receipts per GDP, $G_{i t}$ is the quality of governance, $A_{i t}{ }^{*} G_{i t}$ is the aid-governance interaction term (which represents the impact of aid on food that is conditional on governance), $\operatorname{IV}_{i t}$ are variables that affect aid but are exogenous to undernourishment, $\mathrm{X}_{i t}$ are other exogenous variables that affect food security and the allocation of aid, $\gamma_{t}$ are unobserved time effects, and $\varepsilon_{i t}^{f}$ and $\varepsilon^{a}{ }_{i t}$ are the error terms. Time dummies are included to capture worldwide business cycles.

As instruments for aid I considered following Hansen and Tarp (2001), who used among other variables GDP per capita and a lagged value of the policy index. However, since policy, even in its lagged term, is most likely not exogenous to food security, I turned to Rajan and Subramanian's (2005) instruments instead. In their examination of the aid-growth relationship, they exploited that aid tends to be extended also for non-economic reasons and as instruments used variables capturing strategic and colonial ties. Modifying their example to suit my own data, I use the following variables - three dummy variables that indicate whether the recipient country was ever a British colony, a French colony, or another European colony, the countries' performance in political and civil rights, and the number of deaths in a major disaster. The underlying logic is that donors tend to give more aid to countries with old colonial ties, with better political and civil rights records, and to countries that experienced disasters.

Overall, these variables account for more than 20 per cent of the donors' allocation decision and unlike policy, they are reasonably exogenous to the dependent variable. The colony variables should not be related to food security other than through aid and my initial tests suggested that neither political/civil rights nor disasters were significantly correlated with food security. Another concern is that the instruments could be correlated with governance and thereby violating the exclusion restriction underlying the instrumentation. However, the fact that the correlation coefficient between the instruments and the WGI is low $(<.2)$ and not statistically significant in my sample should allay this worry. The general insignificance of the Sargan tests of over-identifying restrictions and the Durbin-Wu-Hausman tests comparing the IV and OLS estimates further strengthen the instruments' validity ${ }^{[6]}$.

As a second method, I use the system Generalised Method of Moments (GMM) estimator developed by Blundell and Bond (1998) and implemented into Stata by Roodman (2006). My equation in this case is the following:

$$
f_{i t}=f_{i t-1}+\beta_{0}+\beta_{1} A_{i t}+\beta_{2} G_{i t}+\beta_{3}\left(A_{i t} * G_{i t}\right)+\beta_{2} X_{i t}+\gamma_{t}+\varepsilon_{i t}
$$

where $\mathrm{f}_{\mathrm{it}}$ is the prevalence of undernourishment observed for country $i$ in year $t, f_{i t-1}$ is the prevalence of undernourishment in the previous time period ( $t-1), A_{i t}$ are aid receipts per GDP, $G_{i t}$ is the quality of governance, $A_{i t}{ }^{*} G_{i t}$ is the aid-governance interaction term (which represents the impact of aid on food that is conditional on governance), $\mathrm{X}$ it are control variables, $\gamma_{t}$ is the unobserved time effect and $\varepsilon_{i t}$ is the error term.

In the model, I correct for the first-order autocorrelation of the dependent variable and treat aid as endogenous, instrumenting for it with its own lag. The Arellano-Bond test of second- 
order autocorrelation and the Hansen test of the exogeneity of instruments strengthen the model's validity.

When scrutinizing the impact of all aid flows on food security, I report results from both the 2SLS and the GMM regressions. However, since it is impossible to find relevant instruments for all the different types of aid that I examine, I analyze the heterogeneous impacts of the various aid modalities using only the GMM estimator.

\section{Impact of General Aid Flows on Food Security}

Table 2. The effect of general aid flows on food insecurity, using 2SLS and GMM estimators

\begin{tabular}{|c|c|c|c|c|c|c|c|c|}
\hline \multirow{3}{*}{$\begin{array}{l}\text { Model } \\
\text { Food insecurity measure } \\
\text { Food insecurity (lagged) }\end{array}$} & \multicolumn{4}{|c|}{ 2SLS } & \multicolumn{4}{|c|}{ GMM } \\
\hline & \multicolumn{2}{|c|}{ Undernourished } & \multicolumn{2}{|c|}{ Underweight } & \multicolumn{2}{|c|}{ Undernourished } & \multicolumn{2}{|c|}{ Underweight } \\
\hline & & & & & 1.46 & 1.46 & 0.83 & 1.04 \\
\hline & & & & & 16.43 & 16.51 & 14.89 & 15.42 \\
\hline \multirow[t]{2}{*}{ ODA per GDP } & -0.72 & -0.65 & -0.33 & -0.32 & -1.21 & -0.64 & -0.26 & -0.23 \\
\hline & 2.45 & 2.69 & 2.77 & 2.08 & 2.98 & 2.21 & 2.09 & 1.87 \\
\hline \multirow[t]{2}{*}{ Governance } & 2.55 & -0.58 & 0.09 & -0.21 & -0.92 & -0.61 & -0.18 & -1.96 \\
\hline & 0.97 & 1.65 & 0.07 & 0.95 & 2.01 & 1.39 & 0.78 & 1.49 \\
\hline \multirow[t]{2}{*}{ ODA*governance } & & -0.35 & & -0.12 & & -0.21 & & -0.09 \\
\hline & & 1.66 & & 0.93 & & 2.67 & & 1.55 \\
\hline \multirow[t]{2}{*}{ GDP(PPP) p.c. } & -7.96 & -8.50 & -4.45 & -4.67 & -0.90 & -1.37 & -1.44 & -1.14 \\
\hline & 2.88 & 3.44 & 1.87 & 1.78 & 2.13 & 2.85 & 2.59 & 2.86 \\
\hline \multirow[t]{2}{*}{ Population } & -7.54 & -8.70 & -5.70 & -6.73 & -0.38 & -0.40 & -0.65 & -0.66 \\
\hline & 2.87 & 2.58 & 1.97 & 1.98 & 2.41 & 2.53 & 2.71 & 2.73 \\
\hline \multirow[t]{2}{*}{ Food production index } & -0.07 & -0.05 & -0.05 & -0.05 & -0.09 & -0.09 & -0.01 & -0.01 \\
\hline & 3.69 & 2.54 & 2.88 & 2.54 & 4.66 & 4.71 & 1.17 & 1.25 \\
\hline \multirow[t]{2}{*}{ Emergency food aid p.c. } & -0.20 & -0.10 & -0.41 & -0.45 & -0.01 & -0.01 & -0.11 & -0.11 \\
\hline & 1.51 & 1.07 & 3.02 & 3.27 & 1.41 & 0.91 & 2.35 & 2.34 \\
\hline \multirow[t]{2}{*}{ Conflict } & 1.65 & 1.42 & 0.64 & 0.80 & -1.39 & -1.17 & 0.43 & 0.44 \\
\hline & 1.97 & 1.54 & 0.99 & 1.02 & 0.92 & 0.78 & 1.87 & 1.76 \\
\hline \multirow[t]{2}{*}{ LDC } & 0.02 & 0.02 & 0.02 & 0.02 & 3.06 & 3.34 & 1.58 & 1.63 \\
\hline & 1.58 & 2.58 & 2.69 & 1.88 & 2.60 & 2.33 & 1.83 & 1.88 \\
\hline \multirow[t]{2}{*}{ Repayments } & 0.00 & 0.00 & 0.00 & 0.00 & 0.00 & 0.00 & 0.00 & 0.00 \\
\hline & 3.29 & 3.06 & 0.96 & 1.21 & 2.18 & 0.00 & 3.15 & 0.00 \\
\hline$N$ observations & \multicolumn{4}{|c|}{344} & \multicolumn{4}{|c|}{323} \\
\hline$N$ groups & \multicolumn{4}{|c|}{98} & \multicolumn{4}{|c|}{85} \\
\hline AR2 test $($ Prob $>z)$ & & & & & 0.16 & 0.16 & 0.32 & 0.31 \\
\hline Hansen test (Prob> $>2)$ & & & & & 0.59 & 0.58 & 0.16 & 0.19 \\
\hline R2 within & 37.48 & 38.78 & 37.50 & 38.26 & & & & \\
\hline$R 2$ (first stage regression) & 23.55 & 24.12 & 23.91 & 24.51 & & & & \\
\hline DWH test (Prob $>z)$ & 0.24 & 0.97 & 0.07 & 0.06 & & & & \\
\hline Sargan test $($ Prob $>z)$ & 0.81 & 0.73 & 0.32 & 0.32 & & & & \\
\hline
\end{tabular}

Regressions were run with robust standard errors and time dummies. The first number next to each variable is the coefficient; the number below is the corresponding t-statistic. Bold font represents significance at least at the $10 \%$ level.

Table 2 presents results on the impact of total aid flows on food security. Interestingly, all eight regressions in the table indicate the existence of a significant and positive relationship 
between aid and food security, more consistently so than I expected based on the existing research. The coefficients suggest that a one-unit increase in the log of aid per GDP leads to a reduction in the prevalence of undernourishment by $0.6-3$ percentage points and in the proportion of underweight children by $0.2-0.3$ percentage points.

Governance, on the other hand, does not have a consistently positive effect on food security on its own and enhances the effectiveness of aid only when food insecurity is measured through undernourishment prevalence. Figure 1 depicts the conditioning role of governance graphically, showing that in countries with WGI scores below -1.5, such as Burundi or Zimbabwe, aid does not have any significant effect on food security. With improving governance scores the effect of aid becomes increasingly significant and at the high end of the WGI spectrum aid reduces the prevalence of undernourishment by more than 2 percentage points. However, when food insecurity is measured through the prevalence of underweight children, the aid-governance interaction term is not significant although it is still negative in direction. This inconsistent finding on the conditioning role of governance fits relatively well with the existing literature, which is also not united vis-à-vis the question whether governance reinforces the effectiveness of aid.

Figure 1. Average marginal effects of aid conditioned on governance ( $90 \%$ confidence interval)

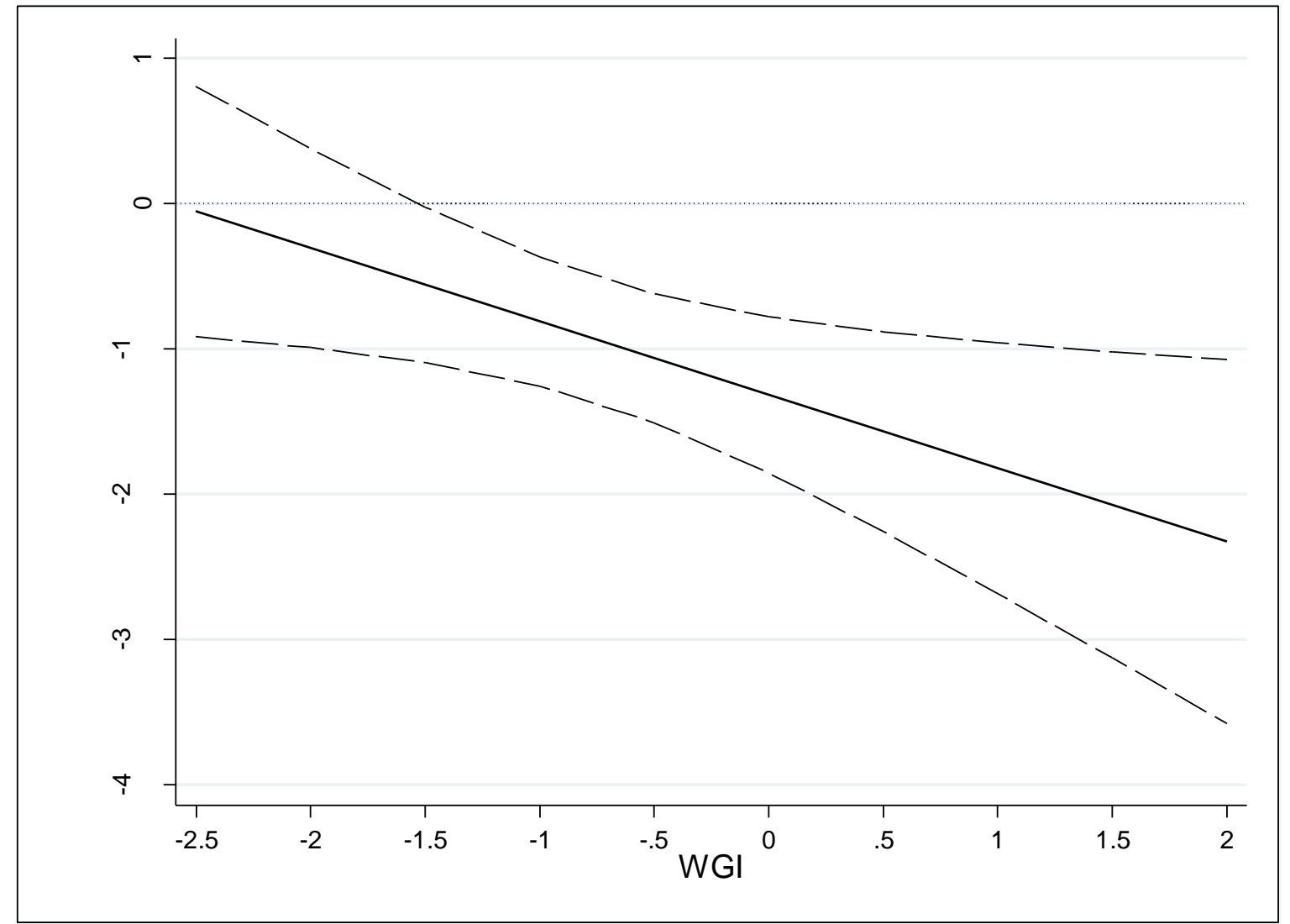

Source: author's own graphic

From the control variables included, the most consistently significant are GDP per capita and the Least-Developed Country dummy. Not surprisingly, countries with higher GDP per capita that are not Least-Developed are on average more food secure. Domestic food production, food aid, and population size strengthen food security as well while conflict and repayments weaken it. The remaining control variables lack a consistently significant relationship with the dependent variables and hence their results are omitted from the table. 
A comparison of the regressions in Table 2 yields several observations. First, the 2SLS and GMM estimators produced similar results, hence bolstering the findings' validity from a statistical point of view. Second, aid appears to strengthen adults' food security more than children's. This difference in impact could be caused by the fact that children's nutritional status is more susceptible to sanitary conditions and health than adults' (Katona and KatonaApte, 2008) and the link between aid on the one side and sanitation and health services on the other is less straightforward than the link between aid and the reduction of financial poverty (which improves people's access to food). Third, as noted already, the aid-governance interaction term is not consistently significant, which goes in line with my conjecture that some types of aid are more susceptible to the quality of governance than others and supports my decision to explore the effects of different aid modalities on food security. Prior to doing so, however, I perform several sensitivity tests to ensure the robustness of the results on the impact of aid in general on food security, in an effort to assess the soundness of the variables and estimators utilized.

\section{Sensitivity Analysis}

As I mentioned above, in the first sensitivity test I substitute the WGI governance variable with the policy index used by Burnside and Dollar (2000). Table 3 displays the results obtained and shows that the substitution does not majorly alter the general conclusions reached in the basic model. Aid still appears to strengthen recipients' food security and the impact is stronger in countries with better governance when food insecurity is approximated by the prevalence of undernourishment. Hence, interestingly, even macroeconomic policies, which are seemingly far removed from food insecurity, improve the effectiveness of aid in its reduction.

Since much of the recent success in improving global food security took place in China and in Brazil, the second sensitivity test involves repeating the aid-food security regressions on a sample of countries that excludes China and Brazil. The results in Table 3 demonstrate that the difference from the original results is very small. This outcome is not surprising seeing that although China and Brazil brought tens of millions of people to food security in the recent decades, my study measures food security in percentages and thus from a statistical point of view, the two countries do not represent extreme outliers.

The third sensitivity check pertains to the fact that throughout the analyses I use data on gross aid rather than on the more commonly utilised net aid. I do so because data on aid categorization is available only for gross aid and as an attempt at remedy I control for repayments. Nevertheless, in Table 3 I examine the impact of aid on food security using data on net aid per capita. The results show that the difference is not overwhelming. The coefficients do vary but the broad inference remains the same - aid reinforces food security and its effect on undernourishment prevalence is conditioned on governance

Finally, as a last robustness check, I introduce an aid-squared variable into the regressions, to examine whether aid in its positive impact on food security has diminishing returns as it does in its effect on growth (e.g. Rajan and Subramanian, 2005). The aid-squared coefficients are indeed significant and positive, corroborating the claim of diminishing returns. However, the core results do not change dramatically - ODA per GDP still appears negative and significant and the interaction variable between aid and governance is negative and significant with undernourishment as food insecurity. 
Table 3. Testing the robustness tests of the basic model

\begin{tabular}{|c|c|c|c|c|c|c|c|c|}
\hline Food insecurity measure & Undernos & hed & Under & & Underno & hed & Underv & \\
\hline & with pc & cy inde & $s$ gover & nce & excl & ing Chi & and $\mathrm{Br}$ & \\
\hline ODA per GDP & -0.97 & -0.94 & -0.28 & -0.26 & -1.23 & -0.75 & -0.18 & -0.17 \\
\hline & 2.17 & 2.11 & 1.92 & 1.95 & 2.10 & 2.24 & 1.74 & 1.70 \\
\hline Governance & -3.78 & -2.24 & 0.65 & 0.29 & -0.59 & -1.04 & -0.17 & -0.26 \\
\hline & 2.14 & 1.91 & 1.07 & 0.75 & 2.00 & 1.88 & 1.53 & 1.75 \\
\hline $\mathrm{ODA}^{*}$ governance & & -0.10 & & 0.00 & & -0.16 & & -0.08 \\
\hline & & 2.17 & & 0.43 & & 2.18 & & 1.56 \\
\hline$N$ of observations & & 32 & & & & 31 & & \\
\hline$N$ of groups & & 8 & & & & 8 & & \\
\hline AR2 test (Prob>z) & 0.135 & 0.230 & 0.113 & 0.742 & 0.122 & 0.189 & 0.115 & 0.291 \\
\hline Hansen test (Prob> $>2$ ) & 0.945 & 0.975 & 0.971 & 0.995 & 0.179 & 0.138 & 0.958 & 0.853 \\
\hline Food insecurity measure & Undernou & hed & Under & & Underno & hed & Underv & \\
\hline & & net OD & er capi & & witl & DA per & P squa & \\
\hline ODA per GDP & & & & & -5.92 & -5.75 & -3.56 & -3.56 \\
\hline & & & & & 2.24 & 2.08 & 2.88 & 2.95 \\
\hline net ODA per capita & -0.78 & -1.59 & -0.33 & -0.13 & & & & \\
\hline & 2.21 & 2.97 & 1.72 & 1.27 & & & & \\
\hline ODA per GDP squared & & & & & 2.52 & 2.44 & 1.59 & 1.60 \\
\hline & & & & & 3.06 & 4.12 & 2.85 & 2.83 \\
\hline Governance & -0.36 & -0.55 & -0.11 & -0.11 & -0.35 & -0.85 & 0.10 & 0.26 \\
\hline & 1.68 & 1.04 & 1.50 & 1.13 & 1.81 & 1.72 & 1.09 & 0.64 \\
\hline ODA*governance & & & & & & -0.35 & & 0.01 \\
\hline & & & & & & 3.29 & & 1.09 \\
\hline net ODA*governance & & -0.33 & & -0.08 & & & & \\
\hline & & 1.87 & & 1.37 & & & & \\
\hline$N$ of observations & & 32 & & & & 32 & & \\
\hline$N$ of groups & & 8 & & & & 8 & & \\
\hline AR2 test (Prob>z) & 0.116 & 0.137 & 0.129 & 0.156 & 0.111 & 0.110 & 0.141 & 0.187 \\
\hline Hansen test (Prob $>\chi 2)$ & 0.954 & 0.893 & 0.903 & 0.946 & 0.796 & 0.721 & 0.896 & 0.918 \\
\hline
\end{tabular}

Regressions were run with robust standard errors and time dummies. The first number next to each variable is the coefficient; the number below is the corresponding t-statistic. Bold font represents significance at least at the $10 \%$ level. The regressions were controlled for the same variables as those in Table 2.

\section{Impact of Different Aid Modalities on Food Security}

Table 4 presents the results of regressions that explore the heterogeneous effects of who provides aid and how aid is provided on recipients' food security. Looking first at the division of aid into bilateral and multilateral, both types have a positive effect, albeit in the case of multilateral aid it is more consistently significant and slightly larger in size. On the other hand, and in line with my initial hypotheses, bilateral aid appears to be more significantly conditioned on the quality of governance than either multilateral aid or aid in general.

Turning attention to the division of aid into grants and concessional loans, grants appear to be much more directly beneficial for food security than loans. However, loans are more consistently conditioned on governance in their effectiveness than grants. While the impact of grants seems positively influenced by the quality of governance only when food insecurity is measured by the prevalence of undernourishment, as is the case with aid in general, the effect 
of loans is conditioned on governance also when food insecurity is approximated by the prevalence of underweight children.

Table 4. The effects of who gives aid and how it is given on recipients' food insecurity

\begin{tabular}{|c|c|c|c|c|c|c|c|c|c|c|c|c|}
\hline \multirow{2}{*}{$\frac{\text { Food insec. measure }}{\text { Aid (ODA) per GDP }}$} & \multicolumn{2}{|c|}{ Undernourished } & \multicolumn{2}{|c|}{ Underweight } & \multicolumn{2}{|c|}{ Undernourished } & \multicolumn{2}{|c|}{ Underweight } & \multicolumn{2}{|c|}{ Undernourished } & \multicolumn{2}{|c|}{ Underweight } \\
\hline & & & & & & & & & \begin{tabular}{|l|}
-0.92 \\
\end{tabular} & -0.61 & -0.22 & -0.20 \\
\hline & & & & & & & & & 2.47 & 2.18 & 1.99 & 1.84 \\
\hline \multirow[t]{2}{*}{ Bilateral aid } & -0.57 & -0.66 & -0.31 & -0.21 & & & & & & & & \\
\hline & 1.91 & 2.26 & 1.93 & 1.61 & & & & & & & & \\
\hline \multirow[t]{2}{*}{ Multilateral aid } & -0.60 & -0.68 & -2.11 & -2.56 & & & & & & & & \\
\hline & 2.16 & 2.31 & 3.82 & 2.88 & & & & & & & & \\
\hline \multirow[t]{2}{*}{ Grants } & & & & & -1.32 & -1.16 & -0.25 & -0.31 & & & & \\
\hline & & & & & 3.29 & 2.31 & 1.91 & 2.10 & & & & \\
\hline \multirow[t]{2}{*}{ Loans } & & & & & 0.12 & 0.68 & -0.04 & -0.17 & & & & \\
\hline & & & & & 0.35 & 1.32 & 0.91 & 1.67 & & & & \\
\hline \multirow[t]{2}{*}{ Budget support } & & & & & & & & & 5.29 & 8.87 & 5.73 & 5.83 \\
\hline & & & & & & & & & 1.48 & 1.82 & 1.51 & 1.55 \\
\hline \multirow[t]{2}{*}{ Governance } & -0.41 & -0.61 & 0.16 & -0.02 & -0.94 & -0.79 & -0.31 & -0.51 & -0.72 & -0.86 & -0.12 & -0.11 \\
\hline & 1.92 & 2.28 & 1.51 & 0.20 & 3.39 & 1.67 & 1.84 & 0.69 & 1.85 & 1.82 & 0.55 & 0.48 \\
\hline \multirow[t]{2}{*}{ Bil. aid* gov } & & -0.26 & & -0.12 & & & & & & & & \\
\hline & & 2.51 & & 2.28 & & & & & & & & \\
\hline \multirow[t]{2}{*}{ Multi.aid*gov } & & -0.05 & & -0.10 & & & & & & & & \\
\hline & & 1.48 & & 1.56 & & & & & & & & \\
\hline \multirow[t]{2}{*}{ Grants*gov } & & & & & & -0.33 & & 0.01 & & & & \\
\hline & & & & & & 1.85 & & 0.21 & & & & \\
\hline \multirow[t]{2}{*}{ Loans*governance } & & & & & & -0.18 & & -0.14 & & & & \\
\hline & & & & & & 1.69 & & 2.04 & & & & \\
\hline \multirow[t]{2}{*}{ Budget support*gov } & & & & & & & & & & -1.76 & & -0.22 \\
\hline & & & & & & & & & & 1.78 & & 1.29 \\
\hline$N$ of observations & \multicolumn{4}{|c|}{323} & \multirow{2}{*}{\multicolumn{4}{|c|}{$\begin{array}{c}323 \\
85\end{array}$}} & \multirow{2}{*}{\multicolumn{4}{|c|}{$\begin{array}{c}323 \\
85\end{array}$}} \\
\hline$N$ of groups & & 85 & & & & & & & & & & \\
\hline AR2 test (Prob $>z)$ & 0.174 & 0.082 & 0.130 & 0.155 & 0.059 & 0.165 & 0.210 & 0.156 & 0.101 & 0.216 & 0.150 & 0.148 \\
\hline Hansen test (Prob $>\chi 2)$ & 0.948 & 0.914 & 0.938 & 0.925 & 0.262 & 0.919 & 0.963 & 0.935 & 0.319 & 0.306 & 0.957 & 0.960 \\
\hline
\end{tabular}

Regressions were run with robust standard errors and time dummies. The first number next to each variable is the coefficient; the number below is the corresponding t-statistic. Bold font represents significance at least at the $10 \%$ level. The regressions were controlled for the same variables as those in Table 2.

Looking at the differential impact of budget support versus program/project aid on food security, the proportion of aid disbursed as budget support is mostly insignificant. Moreover, the interaction variable of budget support with governance is negative and significant in only one of the two regressions. These results suggest that food security is not widely affected by whether aid is implemented through projects or transferred to recipients directly and that in countries with better governance budget support might not have the ability to bolster food security more than in countries with worse governance.

Table 5 presents the results of regressions that look at the impact of aid when divided into agricultural, social, economic, and other. Social aid reduces recipients' food security most consistently and significantly, with a significant effect in all four regressions. Economic aid also appears to have a positive impact on food security, even though it is significant only when food insecurity is measured through the prevalence of undernourishment. Finally, agricultural aid and other aid do not have any significant relationship with food security in their own right, even though the effect of agricultural aid is positively conditioned on governance. 
Table 5. The effects of where aid goes on recipients' food security

\begin{tabular}{|c|c|c|c|c|}
\hline \multirow{2}{*}{$\begin{array}{l}\text { Food insecurity measure } \\
\text { Agricultural aid }\end{array}$} & \multicolumn{2}{|c|}{ Undernourished } & \multicolumn{2}{|c|}{ Underweight } \\
\hline & -0.19 & -0.15 & -0.07 & -0.16 \\
\hline & 1.48 & 1.21 & 0.94 & 1.27 \\
\hline \multirow[t]{2}{*}{ Social infrastructure aid } & -1.77 & -1.66 & -0.57 & -0.56 \\
\hline & 2.88 & 1.87 & 1.90 & 1.66 \\
\hline \multirow[t]{2}{*}{ Economic infrastructure aid } & -1.67 & -1.17 & -0.31 & -0.82 \\
\hline & 2.34 & 2.11 & 0.59 & 1.27 \\
\hline \multirow[t]{2}{*}{ Other aid } & -0.09 & -0.01 & 0.01 & 0.02 \\
\hline & 1.49 & 1.31 & 1.11 & 1.53 \\
\hline \multirow[t]{2}{*}{ Governance } & -0.43 & -1.96 & -0.08 & -0.28 \\
\hline & 1.97 & 2.54 & 2.17 & 0.42 \\
\hline \multirow[t]{2}{*}{ Agricultural aid*governance } & & -0.24 & & -0.16 \\
\hline & & 1.69 & & 2.19 \\
\hline \multirow[t]{2}{*}{ Social aid*governance } & & -0.21 & & -0.01 \\
\hline & & 1.68 & & 1.07 \\
\hline \multirow[t]{2}{*}{ Economic aid*governance } & & -0.31 & & -0.06 \\
\hline & & 1.74 & & 1.29 \\
\hline \multirow[t]{2}{*}{ Other aid * governance } & & 0.01 & & -1.88 \\
\hline & & 0.08 & & 1.28 \\
\hline$N$ of observations & \multicolumn{4}{|c|}{323} \\
\hline$N$ of groups & \multicolumn{4}{|c|}{85} \\
\hline AR2 test (Prob $>z)$ & 0.080 & 0.232 & 0.134 & 0.167 \\
\hline Hansen test $($ Prob $>\chi 2)$ & 0.830 & 0.844 & 0.976 & 0.988 \\
\hline
\end{tabular}

Regressions were run with robust standard errors and time dummies. The first number next to each variable is the coefficient; the number below is the corresponding t-statistic. Bold font represents significance at least at the $10 \%$ level. The regressions were controlled for the same variables as those in Table 2 .

The finding vis-à-vis social and economic aid is interesting yet not completely unforeseen. These two aid categories include aid disbursed to improve water, sanitation, and health services, raise education levels, and provide livelihoods for recipients, and as such were anticipated to strengthen food security at least to some extent. The more surprising finding is with regard to agricultural aid, which I expected to have the most significant positive effect of the four types of aid and discovered none. This lack of significance does not imply that agricultural aid cannot play a meaningful role in strengthening food security, given that the contrary has often been proven on the micro level (e.g. IYCN, 2011). Instead, the more likely explanation is that not all aid to agriculture strengthens food security, a suspicion reinforced by the fact that agricultural aid is also the type of aid whose influence is most significantly conditioned on governance.

\section{Discussion}

Much of the data available for quantitative cross-country studies is believed to be imperfect. This might not be true regarding data on aid but is almost certainly true regarding data on food security and on governance, two of the main concepts examined within this paper. However, I have tried hard to overcome this problem by providing a number of robustness checks on the results obtained. Consequently, the findings paint a picture that perhaps does not replicate but surely at least closely resembles the reality. 
My first key finding is that development assistance has a possibly small but significant positive impact on food security, whether measured by the prevalence of undernourishment or of underweight children. The magnitude of the regression coefficients is somewhat sensitive to changing specifications but the empirical models that tested the aid-food security relationship consistently showed positive significance. The conclusion that aid bolsters food security is further supported by the fact that there is likely to be a slight downward bias in the results as aid and food security have a naturally negative association - since more aid goes to countries with lower food security.

The second key finding is that the effect of aid and the degree to which it is influenced by the quality of recipients' governance varies based on the type of aid provided. When looked at as a uniform flow, aid appeared to be conditioned on governance only when food security was expressed as undernourishment prevalence. However, in line with my hypotheses, I found bilateral aid and loan aid to be conditioned on governance more consistently and significantly than their counterpart types of aid - multilateral and grant aid - as well as aid in general. I also expected to find budget support to be more influenced by governance than program and project aid since, similar to loan aid, it requires a greater amount of action and discipline from the receiving governments but the results failed to validate this view.

Because many aid agencies use stricter policy conditionality when disbursing budget support than with other aid instruments, the first explanation for this non-finding that comes to mind is that budget support is provided only to countries with above-average governance scores and hence governance can no longer appear to condition its effectiveness as it would if budget support were provided to all developing countries indiscriminately. A cursory look at the data, however, discredits this argument. A simple t-test showed that the recipients of budget support had actually significantly lower governance scores than non-recipients. An alternative explanation could be that the size of aid flows in the form of budget support is too small relative to the size of program and project aid flows to uncover any statistical significance. This question would, however, undoubtedly benefit from further research.

The same can be said with regard to the effects of agricultural aid. When looking at the impact of different aid modalities on food security independent of the influence of governance, bilateral aid, multilateral aid, grant aid, and social and economic aid were found to have a significantly positive effect as expected, while agricultural aid - hypothesized to have a stronger positive influence on food security than aid to any other sector - appeared insignificant. This finding is surprising since most aid projects focused specifically on strengthening food security revolve around agriculture and have often been proven successful. The consistent significance of the agricultural aid-governance interaction term implies that the likely explanation is that agricultural aid is highly susceptible to the quality of recipients' institutions and policies and influences food security positively only in countries with better governance.

Nevertheless, only a more in-depth analysis would be able to elucidate the underlying mechanisms more clearly. Further research could also explore in more detail the interactions among the different aid modalities, for example the different effects of grants versus concessional loans to agriculture. However, such studies would probably be more accurate if undertaken at an individual country level.

\section{Conclusion}

Due to persistent population growth, stagnating crop yields, and deteriorating climate conditions, food insecurity is likely to pose ever-increasing global challenges. In this study, I demonstrate that aid, despite its many deficiencies, can play a positive role in addressing the issue. Moreover, I show that the impact of aid on food security is heterogeneous in that some aid instruments have a more positive impact than others in their own right while others are 
more susceptible to the quality of recipients' institutions and policies. Future research could deepen the robustness of these findings and extend the use of the aid categorization to the assessment of aid effectiveness in achieving other desirable development outcomes, such as growth or economic equality.

[1] The way the body metabolizes the food consumed, influenced by the type of food, one's health, and sanitary conditions (FAO).

[3] 'Other' aid comprises primarily aid to industry, construction, trade, and tourism.

${ }^{[4]}$ Certainly, even non-poor people can be food insecure but such occurrence is relatively uncommon. Moreover, since internationally comparable measures of poverty are scarce, food insecurity can even be regarded an acceptable proxy variable for poverty.

${ }^{[5]}$ In the robustness regressions with the weighted policy index, I exclude trade openness as it is included in the index.

${ }^{[6]}$ In 2SLS regressions where the interaction term with WGI is used, I instrument for it by its multiplication with all the instrumental variables (Wooldridge, 2002) 


\section{References}

Abdellatif, A.M. (2003), "Good governance and its relationship to democracy and economic development", in Global Forum III on Fighting Corruption and Safeguarding Integrity, UNCDP, Seoul, Korea.

Barrett, C. (2002), "Food security and food assistance programs", in Handbook of Agricultural Economics, Elsevier, Amsterdam, pp. 1-95.

Berg, A. and Krueger, A. (2003), Trade, Growth, and Poverty: A Selective Survey. IMF, Washington, D.C.

Berti, P.R., Krasevec, J. and FitzGerald, S. (2004), "A review of the effectiveness of agriculture interventions in improving nutrition outcomes", Public Health Nutrition, Vol. 7 No. 5, pp. 599-609.

Bhavan, T., Xu, C. and Zhong, C. (2011), "Growth effect of foreign aid and volatility in South Asia”, International Journal of Development Issues, Vol. 10 No. 3, pp. 204-213.

Bhutta, Z.A., Ahmed, T., Black, R.E., Cousens, S., Dewey, K., Giugliani, E. ... and Shekar, M. (2008), "What works? Interventions for maternal and child undernutrition and survival", The Lancet, Vol. 371 No. 9610, pp. 417-440.

Bulír, A. and Hamann, A. J. (2008), "Volatility of development aid: From the frying pan into the fire?", World Development, Vol. 36 No. 10, pp. 2048-2066.

Bullow, J. and Rogoff, K. (2005), "Grants versus loans for development banks", American Economic Review, Vol. 95 No.2, pp. 393-397.

Burnside, C. and Dollar, D. (2000), "Aid, policies, and growth", The American Economic Review, Vol. 90 No.4, pp. 847-868.

Clemens, M., Radelet, S. and Bhavnani, R. (2004), "Counting chickens when they hatch: The short-term effect of aid on growth", Center for Global Development Working Paper, No. 44.

Clements, B., Gupta, S., Pivovarsky, A. and Tiongson, E.R. (2004), "Foreign aid: Grants versus loans", Finance and Development, Vol. 41 No. 3, pp. 46-9.

Cohen, J. (1995), How Many People Can the Earth Support?, W.W. Norton, New York, N.Y.

Cordella, T. and Dell'Arriccia, G. (2003), "Budget support versus project aid", IMF Working Paper, Vol. 3 No. 88,

Crola, J. (2009). Aid for Agriculture: Turning Promises into Reality on the Ground. Oxfam, London, UK.

Del Ninno, C., Dorosh, P. and Subbarao, K. (2007), "Food aid, domestic policy and food security: Contrasting experiences from South Asia and sub-Saharan Africa", Food Policy, Vol. 32 No.4, pp. 413-435.

Devarajan, S. and Swaroop, V. (1998), "The implications of foreign aid fungibility for development assistance", World Bank Working paper, Vol. 2022.

Dinour, L.M., Bergen, D. and Yeh, M.C. (2007), "The food insecurity-obesity paradox: a review of the literature and the role food stamps may play", Journal of the American Dietetic Association, Vol. 107, No. 11, pp. 1952-61.

Djankov, S., Montalvo, J. and Reynal-Querol, M. (2006), "Does foreign aid help?" Cato Journal, Vol. 26 No. 1, pp. 1-28.

Doucouliagos, H. and Paldam, M. (2009), "The Aid effectiveness literature: The sad results of 40 years of research", Journal of Economic Surveys, Vol. 23 No.3, pp. 433-461.

Dreher, A., Nunnenkamp, P. and Thiele, R. (2008), "Does aid for education educate children? Evidence from panel data", The World Bank Economic Review, Vol. 22 No.2, pp. 291-314.

Dreze, J. (2004), "Democracy and right to food", Economic and Political Weekly, Vol. 39 No. 17, pp. 1723-31.

G8 (2009), "L’Aquila summit: Chair's summary", available at: http://ec.europa.eu/economy _finance/publications/publication15572_en.pdf (accessed 1 July 2014). 
G8 (2012), "G-8 action on food security and nutrition", available at: http://www.mofa.go.jp/mofaj/gaiko/summit/camp_david12/pdfs/side_event_02.pdf (accessed 1 July 2014).

Hansen, H. and Tarp, F. (2001), "Aid and growth regressions", Journal of Development Economics, Vol. 64 No. 2, pp. 545-570.

Hoque, B.A., Juncker, T., Sack, R.B., Ali, M. and Aziz, K.M. (1996), "Sustainability of a water, sanitation and hygiene education project in rural Bangladesh: a 5-year follow-up", Bulletin of the World Health Organization, Vol. 74 No. 4, pp. 431-7.

IYCN (2011), Nutrition and Food Security Impacts of Agriculture Projects, IYCN, Washington, DC.

Kang, S. and Meernik, J. (2005), "Civil war destruction and the prospects for economic growth", Journal of Politics, Vol. 67 No.1, pp. 88-109.

Katona, P. and Katona-Apte, J. (2008), "The interaction between nutrition and infection", Clinical Infectious Diseases, Vol. 46 No. 10, pp. 1582-8.

Kormendi, R.C. and Meguire, P.G. (1985), "Macroeconomic determinants of growth: crosscountry evidence", Journal of Monetary Economics, Vol. 16 No.2, pp. 141-63.

Kosack, S. (2003), "Effective aid: How democracy allows development aid to improve the quality of life", World Development, Vol. 31 No.1, pp. 1-22.

Leisinger, K., Schmitt, K. and Pandya-Lorch, R. (2002), Six Billion and Counting: Population Growth and Food Security in the 21 st Century, IFPRI, Washington, DC.

Lensink, R. and White, H. (2001), “Are there negative returns to aid?", Journal of Development Studies, Vol. 37 No. 6, pp. 42-65.

Masud, N. and Yontcheva, B. (2005), "Does Foreign Aid Reduce Poverty? Empirical Evidence from Nongovernmental and Bilateral Aid", IMF Working Paper.

Michaelowa, K. and Weber, A. (2007), "Aid effectiveness in the education Sector - A dynamic panel analysis", in S. Lahiri (Ed.), Theory and Practice of Foreign Aid, Elsevier, Amsterdam, pp. 357-385.

Mishra, P. and Newhouse, D. (2007), "Health aid and infant mortality", IMF Working Paper, No. 7.

Odedokun, M. (2004), "Multilateral and bilateral loans versus grants: Issues and evidence", The World Economy, Vol. 27 No.2, pp. 239-263.

Organization for Economic Development (2003). "Official Development Assistance", available at: http://stats.oecd.org/glossary/detail.asp? ID=6043 (accessed 12 January 2014).

Rajan, R. and Subramanian, A. (2008), "Aid and growth: What does the cross-country evidence really show?", Review of Economics and Statistics, Vol. 90 No. 4, pp. 643-65.

Roodman, D. (2006). "How to do xtabond2: An introduction to difference and system GMM in Stata", Center for Global Development Working Paper, No. 103.

Scully, G.W. (1988), "The institutional framework and economic development", Journal of Political Economy, pp. 652-662.

Svedberg, P. (2000), Poverty and Undernutrition: Theory, Measurement, and Policy. Oxford UP, Oxford, UK.

Webb, P. (2010), "Medium-to long-run implications of high food prices for global nutrition", The Journal of Nutrition, Vol.140 No.1, pp. 143S-7S.

Wooldridge, J.M. (2002), Econometric Analysis of Cross-Section and Panel Data, MIT, Cambridge, MA. 